PRAGATI: Journal of Indian Economy Volume 4, Issue 1, January-June 2017, pp. 83-92 doi:10.17492/pragati.v4i01.9543

\title{
A Discussion on India's Manufacturing Sector: Weaknesses and the Way Forward
}

\author{
Deepti Kakar*
}

\begin{abstract}
Despite the significant role of the tertiary sector to national growth and employment generation, there is no denying to the importance of the manufacturing sector which has the potential to bring stable and sustainable growth for Indian economy in the long run. However, the industry has not grown at the desired speed and has not generated enough employment opportunities. In light of the critical nature of the manufacturing sector as a contributor to economic growth and development, governmental interventions such as policy level changes and provisioning of incentives and relaxations on starting, sustaining and expanding operations in this sector, have been made. However, the gains have not been commensurate to the push being provided. Thus, it becomes important to explore and understand that the right impetus on the right points. This paper attempts to meet three objectives - to examine the current state of Indian manufacturing sector, to identify the major reasons for the ailing manufacturing sector and to suggest measures in the form of policy prescriptions or reforms which can make a credible and positive difference to the state of manufacturing in India. The three objectives are sequentially discussed and achieved by use of secondary data sources that include existing accessible research studies, governmental and institutional databases and relevant books.
\end{abstract}

Keywords: Manufacturing sector; Indian economy; Infrastructure; Technology; Regulations.

\subsection{Introduction}

The decade of 1990s has been rightly remarked as an eventful period for the Indian economy. The liberalisation-privatisation-globalisation phenomenon was directed to reform the course of the then crisis laden economic situation into one with opportunities to bring about goal- achievement for national economy.

*Professor, Jagan Institute of Management Studies, Delhi, India.

(Email id:deeptikakar@jimsindia.org) 
Specifically, the efforts to restructure the industrial framework of the country after 1991 were "more fundamental in nature as compared to the marginal changes" (Ahluwalia, 1995) which had been initiated in the 1980s. The reformed policy directives included significant changes in the regulatory environment for businesses. Most of the steps taken were attempts to improve the domestic as well as global competitiveness of Indian businesses (Kapila, 2008). The realisation and acknowledgement of the need and importance of foreign capital in production processes and thus its requirement for economic growth and development was also visible in the form of relaxed norms for foreign direct and portfolio investment (Kakar, 2016). Though these changes can be hailed as an announcement for a superior course of action, the outcomes in terms of improved economic growth were not evident immediately.

Gradually economic growth in India soared, crossed 9\% per annum in 2006-07 and managed to reach an average annual rate of 7.6\% for the period 2001-02 to 2009-10 (GOI, 2015). This growth performance of the Indian economy has been largely on account of the impressive contribution made by the tertiary or the services sector. The contribution of the secondary or the industrial sector has been stubborn to any commendable improvements. The structural transformation that accompanies an economy's growth (Rostow, 1960) has not been conspicuously discernible in Indian context. With time, India has experienced a decline in the contribution of the primary activities to the GDP but the baton was not taken up by the secondary sector and instead the services have emerged as the frontrunners in the country's growth story. Thus, Kuznets's pattern of economic growth (Kuznets, 1973) has been defied by India which moved from an agrarian economy to a service economy. This combined with more than half of the population continuing to earn its livelihood from primary activities, speaks of a kind of structural distortion and failure of the secondary and tertiary sector to offer employment opportunities to aid the structural shift in the economy. This pre-mature shift has been analysed and debated for the exceptional experience of our economy and also the practical sustainability of services led economic growth in the long run. The state and progress of the secondary sector (mainly comprising of the manufacturing) in India is a definite cause of worry.

The significance of the manufacturing sector cannot be over emphasised and there is ample evidence from the rest of the world to prove that industrial base and its growth is indispensable to bring about economic growth. Thirwall (1983) has explained the Kaldor hypothesis that shows the strength and potential of the manufacturing sector to contribute to the national output at an increasing rate relative to the proportionate increase in the inputs involved in the sector. Dasgupta and Singh (2005) have researched on the validity of the hypothesis for a number of countries and have been able to 
establish a strong connect between the growth in the manufacturing sector and GDP growth. Interestingly, their studies have shown a weak relationship between the growth in primary and tertiary activities and economic growth. Another study by Adugna (2014) for Ethiopia and by Tsoku et al. (2017) on South Africa confirms Kaldor's first law of growth and suggests the importance of emphasizing on the growth via investment in manufacturing sector to take the economy to higher levels of growth.

\subsection{Indian Manufacturing Sector: Current State}

In the recent past, the manufacturing sector has shown sluggish growth. Table 1 exhibits the growth rates achieved by the different sub-sectors of the industrial economic activity over the last ten years. The dismal performance of the manufacturing alone as well as the overall industrial sector over 2011-13 has gradually given way to encouraging growth rates in the past two years. In addition to manufacturing, the industry as a sector comprises of mining, quarrying, construction, electricity, gas and water supply. As manufacturing makes the bulk of the industrial activities, its significance in policy making and national level as well as global discussions is not misplaced.

Table 1: Industry and Sub-component Growth Rates at Constant Prices (2004-05)

\begin{tabular}{|c|l|c|c|c|c|c|c|c|c|c|c|}
\hline No. & \multicolumn{1}{|c|}{ Sector } & $\begin{array}{c}\mathbf{2 0 0 7}- \\
\mathbf{0 8}\end{array}$ & $\begin{array}{c}\mathbf{2 0 0 8}- \\
\mathbf{0 9}\end{array}$ & $\begin{array}{c}\mathbf{2 0 0 9}- \\
\mathbf{1 0}\end{array}$ & $\begin{array}{c}\mathbf{2 0 1 0} \\
\mathbf{1 1}\end{array}$ & $\begin{array}{c}\mathbf{2 0 1 1} \\
\mathbf{1 2}\end{array}$ & $\begin{array}{c}\mathbf{2 0 1 2} \\
\mathbf{1 3}\end{array}$ & $\begin{array}{c}\mathbf{2 0 1 3} \\
\mathbf{1 4}\end{array}$ & $\begin{array}{c}\mathbf{2 0 1 4} \\
\mathbf{1 5}\end{array}$ & $\begin{array}{c}\mathbf{2 0 1 5} \\
\mathbf{1 6}\end{array}$ & $\begin{array}{c}\mathbf{2 0 1 6} \\
\mathbf{1 7}\end{array}$ \\
\hline 1 & $\begin{array}{l}\text { Mining and } \\
\text { quarrying }\end{array}$ & 3.7 & 2.1 & 5.9 & 4.9 & -0.6 & 1.0 & 5.0 & 7.0 & 7.0 & 8.5 \\
\hline 2 & Manufacturing & 10.3 & 4.3 & 11.3 & 9.7 & 2.7 & 2.2 & 6.0 & 8.5 & 9.5 & 9.5 \\
\hline 3 & $\begin{array}{l}\text { Electricity, gas } \\
\text { and water supply }\end{array}$ & 8.3 & 4.6 & 6.2 & 5.2 & 6.5 & 5.2 & 7.5 & 8.0 & 8.0 & 8.0 \\
\hline 4 & Construction & 10.8 & 5.3 & 6.7 & 10.2 & 5.6 & 8.0 & 8.0 & 8.5 & 10.0 & 11.0 \\
\hline 5 & Industry (1-4) & 9.7 & 4.4 & 9.2 & 9.2 & 3.5 & 4.0 & 6.6 & 8.4 & 9.4 & 9.8 \\
\hline
\end{tabular}

Sources: https://data.gov.in/sites/default/files/datafile/Table_2.1.xls;indiabudget.nic.in

The IIP or the Index of industrial production (which captures the changes in the volume of production output) based on 2004-05 prices has shown a steady increase over the years 2005-06 to 2015-16 (Table 2) except for a decline in 2013-14. In May 2017, the Government of India announced revision of base year for calculation of IIP from 
2004-05 to 2011-12. Thus the IIP for 2016-17 stands out of the ongoing trend due to the said change in the base year.

Though the annual growth in the manufacturing sector has on an average been far better than many other nations, the 2016 UNIDO report confirms an extremely low per capita manufactured value added for India as well as a fall in the share of manufactured value added in GDP (as in Table 3). The former is reflective of the per person income generated by the manufacturing sector. In the report, the competitiveness of the manufacturing sector has been ranked for all the countries of the world. This in effect showcases the relative impact of a country's industrial potential in the national and global markets by improving productivity and value additions by volume expansions and technological improvements. According to the said report, India is ranked at 43 with 0.083 as the Competitive Industrial Performance Index, CIP Index for 2013.

Table 2: Index of Industrial Production

\begin{tabular}{|c|c|c|c|c|}
\hline Year & Mining and Quarrying & Manufacturing & Electricity & General \\
\hline $2007-08$ & 112.5 & 150.1 & 120.0 & 141.7 \\
\hline $2008-09$ & 115.4 & 153.8 & 123.3 & 145.2 \\
\hline $2009-10$ & 124.5 & 161.3 & 130.8 & 152.9 \\
\hline $2010-11$ & 131.0 & 175.7 & 138.0 & 165.5 \\
\hline $2011-12$ & 128.5 & 181.0 & 149.3 & 170.3 \\
\hline $2012-13$ & 125.5 & 183.3 & 155.2 & 172.2 \\
\hline $2013-14$ & 124.7 & 181.9 & 164.7 & 172.0 \\
\hline $2014-15$ & 126.5 & 186.1 & 178.6 & 176.9 \\
\hline $2015-16$ & 129.3 & 189.8 & 188.7 & 181.1 \\
\hline $2016-17^{*}$ & 98.7 & 119.3 & 144.5 & 118.3 \\
\hline
\end{tabular}

Sources: https://dbie.rbi.org.in/DBIE/dbie.rbi? site=publications; www.mospi.nic.in *(New Base 2011-12 = 100)

Table 3: India's Manufactured Value Added

\begin{tabular}{|c|c|c|}
\hline Year & MVA per capita at 2005USD & Share of MVA in GDP \\
\hline $\mathbf{2 0 0 8}$ & 131.9 & 15 \\
\hline $\mathbf{2 0 1 3}$ & 161.7 & 14 \\
\hline
\end{tabular}

Source: Industrial Development Report 2016, UNIDO 


\subsection{Slow Manufacturing Sector: Underlying Reasons}

The other comparable economies of the world have shown substantial increases in their manufacturing and some emerging economies have made remarkable growth turning their manufacturing sector into harbinger of growth for the economy (Kapila, 2008). The Indian case has however stood out for the non-spectacular performance of the manufacturing sector. The well-recognized reasons for the weak position of the manufacturing in India and slow improvements in the same lie in three major areas, namely - low level of technology, inadequate infrastructure and higher cost of production. Not only are these factors interlinked with each other, they also reinforce each other and cause the manufacturing sector to continue to be an underperformer.

It is significant to note the structure of the manufacturing sector in India which comprises of largely small scale enterprises operating in an informal setup. The large scale operators, on the other hand are fewer in numbers. Though the small scale units have contributed a lot in terms of national income, foreign exchange earnings (through export income) and employment generation, they have remained low on productivity, also the gains thereon, low on research and development and therefore low on profitability. For example the micro level enterprises, make for about 60 percent of manufacturing employment in India. A research by Porta and Schleifer (2008) based on firm level data from World Bank surveys upholds this through its finding that the large number of small firms in informal setup may be job providers to a large number but are short lived and unable to sustain themselves let alone sustain their contribution to the development of the economy. As per the study (Porta and Schleifer, 2008) the value added per worker was $\$ 1,450$ in small firms, $\$ 5,223$ in medium-sized firms and $\$ 13,089$ for large firms in India in the year 2005. Thus, according to the researchers, if there is any positive hope from the manufacturing sector, it can be fulfilled by the small proportion of relatively large scale manufacturing units that use more capital, skilled manpower and have technological applications in operations and marketing of products in a formal setup.

Inadequate capital and its relative scarcity have been significant among the various reasons for low level of technology usage and research and development focus in Indian manufacturing. Therefore, indigenous innovations and developing grounds for technological advancements remain malnourished. Import of technology or technology transfer from across the national boundaries too remains on account of low level of capital availability. These adversely affect the quantity and quality of the output produced. The 2016 UNIDO report affirms that India lags in technological application. 
In addition to the inadequacy of capital as an essential input to drive the research and development, is the legal protection extended to the innovator via the intellectual property rights. The ambiguities in the Indian laws governing Intellectual Property Rights and their variation from the global standards have also been instrumental in fizzling out the creativity and innovative spirit that founds all research and development activities. The US Chamber of Commerce's Global Intellectual Property Center had put India at the $29^{\text {th }}$ position out of 30 nations in 2015 ranking at the IP (Intellectual Property) index.

To top these difficulties, is the lack of infrastructure vital to the establishment and working of the manufacturing sector. The gap between the availability and requirement of physical infrastructure is huge and in turn creates hurdles for the other linked economic activities. A PwC report (2012) had clearly pointed at the infrastructure deficit and quantified the improvement potential in the Indian manufacturing sector's growth at $3 \%$ per annum if the deficit could be done away. Yet another factor that has contributed in ensuring continued weakness of the Indian manufacturing has been the inefficient support extended by the State. Though we have had clearly specified Industrial Policy resolutions explicitly defining goals for the sector and also strategies to achieve the same were also put forward. Learning from the past experience with the foreigners, private players and socialistic leanings of the then political leaders were visible in the governmental controls and industrial licensing regime that stayed for more than four decades in the post-independence India. Kapila (2008) upholds that the controls were a part of the five-year plan documentation, foreign exchange rule, foreign trade policy, credit rationing and price controls. These restrictions effected the restrictions on the growth of this industry. With the change towards liberalization, privatization and globalisation that came via the economic reforms of 1991, the protection enjoyed by most small operators in this sector vanished and the inefficiencies of the industry stood exposed to competition from the foreign players. Thus the good implications of the policy change were overshadowed by the weaknesses of the Indian industry. On the other hand, the big businesses sought cost reductions by moving towards cheaper imports for raw materials and components.

The support required from the State has been largely missing and bureaucratic delays, multiple formalities, ambiguities in the laws and procedural norms, along with the starkly inadequate infrastructure puts India lowly on the 'Ease of doing business' in the world rankings. World Bank (2017) ranks India at 130 among 190 nations for the year 2016 way behind China and also Nepal and Sri Lanka.

All these clearly translate into a weak manufacturing base which is unlikely to take over the service sector as the leading contributor to the national income. The weak 
manufacturing base makes the price and quality of the output generated by the Indian manufacturing sector uncompetitive on the global platform. It has been only the labour intensive manufacturing units such as leather and textiles where India has been able to showcase commendable performance. Small scale production with capital constraint and weak $\mathrm{R} \& \mathrm{D}$, together with bureaucratic apathy has lent an inefficient trait to the manufacturing in India.

\subsection{Strengthening the Manufacturing Sector: Suggestive Measures}

The web of factors identified in the previous section clearly point to the need for multiple and concerted efforts to enable the manufacturing to overcome the slow pace and leapfrog into a vanguard of income and employment generator in Indian economy. In the background of the identified and well acknowledged factors causing the present state of weak manufacturing sector, it is evident that most of the concerted efforts need to originate from the State. The inadequacy of capital, the missing infrastructure and technological backwardness of the Indian manufacturing need to be corrected with initiatives coming in full force and getting implemented.

\subsection{Undo the excessive regulation}

Regulatory role of the State is significant in the light of the imperfections of the market system and the growing concern for environment and also labour rights and much desired consumer protection. However, excessive control can cause to impede the operations and planned expansions of economic activities. This has been the experience of the industrial sector. The license-permit regime imposed heavy fetters in the functioning of the manufacturing units. Ranked as one of the least friendly place to do business, the ambiguities in different laws directly and indirectly affecting manufacturing businesses must be streamlined. These more specifically include the laws related to taxation, labour, environmental pollution and land acquisition. Big players may lobby with their political contacts and manage to get things moving in the desired direction; however the vast majority of small players in the industry face severe problems in understanding and complying with unwanted formalities. The law making machinery must be mad more predictable to lessen the uncertainty tagged with Indian policy making and change thereon.

\subsection{Infrastructure development}

Correcting infrastructure gap is another step required to create the foundational base for the new establishments in this sector. A healthy and reliable infrastructure 
especially in power and transportation is extremely critical to the growth and sustenance of manufacturing sector. Investments in infrastructure are clearly on the right move but the gap is still loud. Infrastructure development is famous for its multiplier effect on the growth in other sectors and eventually the national income. Specifically, development of infrastructure is likely to give the much wanted impetus to the growth in many component sectors like automobiles, steel and cement. As is visible there is lack of interest of the private sector investment in many infrastructure projects which should be overtaken by public sector investment. Logistic support is another weak area whose support is very much required by the manufacturing as well as the primary sector activities. Greater investment in infrastructure is a sure solution to improve the industrial performance.

\subsection{Strengthen research and development}

The application of technology in the manufacturing sector is mostly basic and most of the players are constrained to further its development which as discussed earlier causes to affect the quality and price competitiveness of India's manufacturing output. Although most of the units have some basic standardized use of technology, it is best described as mechanized replication and capabilities to further the product design or bring process improvements via technological application are extremely meagre. It is only the automobile component sector that makes use of advanced technology.

It is important to note that superior quality of human resources especially scientists and engineers are essential to kindle the innovative spirit. Though India has a commendable pool of high quality scientists and engineers, the innovation enabling environment including the financial support is required. Also, the challenge from labour displacing technological advancements getting discouraged tends to nip further improvements and traps the operations in inefficient processes. This misdirects technological progress away from efficiency. In addition, the opportunities available to the talent pool in other parts of the world, causes brain-drain which is detrimental to encashing the potential of all the economic activities. Therefore it is significant to create an environment conducive to nurturing scientific temper and growth of innovative talent. A measurable step in the direction can be in the form of increased investment in Research and Development facilities for different application areas across the country.

\subsection{Conclusion}

Having identified the significance of the manufacturing sector for India's growth, the current state of the sector and the reasons underlying the weakness of this 
sector, we have been able to suggest three measures that need to be taken, not sequentially but simultaneously to ensure that the sector rises above its snail pace. It is significant to note that though this sector is inherently fraught with structural problems that hold back most of the players from the application of technological improvement and ability to reap economies of scale, the external structure of the business environment (including the regulators, infrastructure and $\mathrm{R} \& \mathrm{D}$ culture) is very critical to make or break the future of an entrant or incumbent in the manufacturing sector.

Given the willingness of the present government to strengthen the manufacturing sector via a number of initiatives in the form of National Investment and Manufacturing Zones and 'Make in India' campaign, there has emerged a hope of creation of an environment that would facilitate the manufacturing sector to scale efficiency, improve its competitiveness, growth and contribution to the economic growth.

\section{References}

Adugna, T. (2014). Impacts of manufacturing sector on economic growth in Ethiopia: A Kaldorian approach. Journal of Business Economics and Management Sciences, 1(1), 18. Retrieved from http://journaldynamics.org/wp-content/uploads/2014/11/Teshome.pdf

Ahluwalia, M. S. (1995). India's economic reforms. In Cassen Robert \& Vijay Joshi (Eds.), The future of economic reforms (pp. 11-18). New Delhi: Oxford University Press.

Dasgupta, S. \& Singh A. (2005). Will services be the new engine of Indian economic growth? Centre for Business Research, University of Cambridge, Working Paper No. 310. Retrieved from https://www.cbr.cam.ac.uk/fileadmin/user_upload/centre-forbusiness-research/downloads/working-papers/wp310.pdf

Government of India. (2015). GDP growth rate of India (Constant Prices) during 200102 to 2013-14. Retrieved from https://community.data.gov.in/gdp-growth-rate-of-indiaconstant-prices-during-2001-02-to-2013-14/

Kakar, D. (2016). India's political environment: A review of pro-business shift. Pravara Management Review, 15(1), 9-14.

Kapila, U. (2008). Indian economy: Performance and policies. New Delhi: Academic Foundation. 
92 | PRAGATI: Journal of Indian Economy, Volume 4, Issue 1, January-June 2017

Kuznets, S. (1973). Modern economic growth: Findings and reflections. American Economic Review, 63(3), 247-258. Retrieved from http://www.sfu.ca/ dandolfa/ kuznets.pdf

Porta, L. R. \& Shleifer, A. (2008). The unofficial economy and economic development. NBER Working Paper No. 14520, December. Retrieved from http://www.nber.org/ papers/w14520

Rostow, W. W. (1960). The five stages of growth: A summary, The stages of economic growth: A Non-Communist Manifesto (pp. 4-16). Cambridge: Cambridge University Press. Retrieved from https://www.ou.edu/uschina/gries/articles/IntPol/Ros tow.1960.Ch2.pdf

Thirwall, A.P. (1983). A plain man's guide to Kaldor's Growth laws. Journal of Post Keynesian Economics. 5(3), 345-358.

Tsoku, J.T., Mosikari, T.J., Xaba, D. \& Modise, T. (2017). An analysis of the relationship between manufacturing growth and economic growth in South Africa: A cointegration approach. International Journal of Social, Behavioural, Educational, Economic, Business and Industrial Engineering. 11(2), 428-433.

UNIDO. (2016). The Role of Technology and Innovation in Inclusive and Sustainable Industrial Development. Industrial Development Report 2016. Retrieved from https://www.unido.org/fileadmin/user_media_upgrade/Resources/Publications/EBOOK_ IDR2016_FULLREPORT.pdf

World Bank. (2017). Ranking of economies - Doing business. Doing Business Report Series. Retrieved from http://www.doingbusiness.org/rankings 